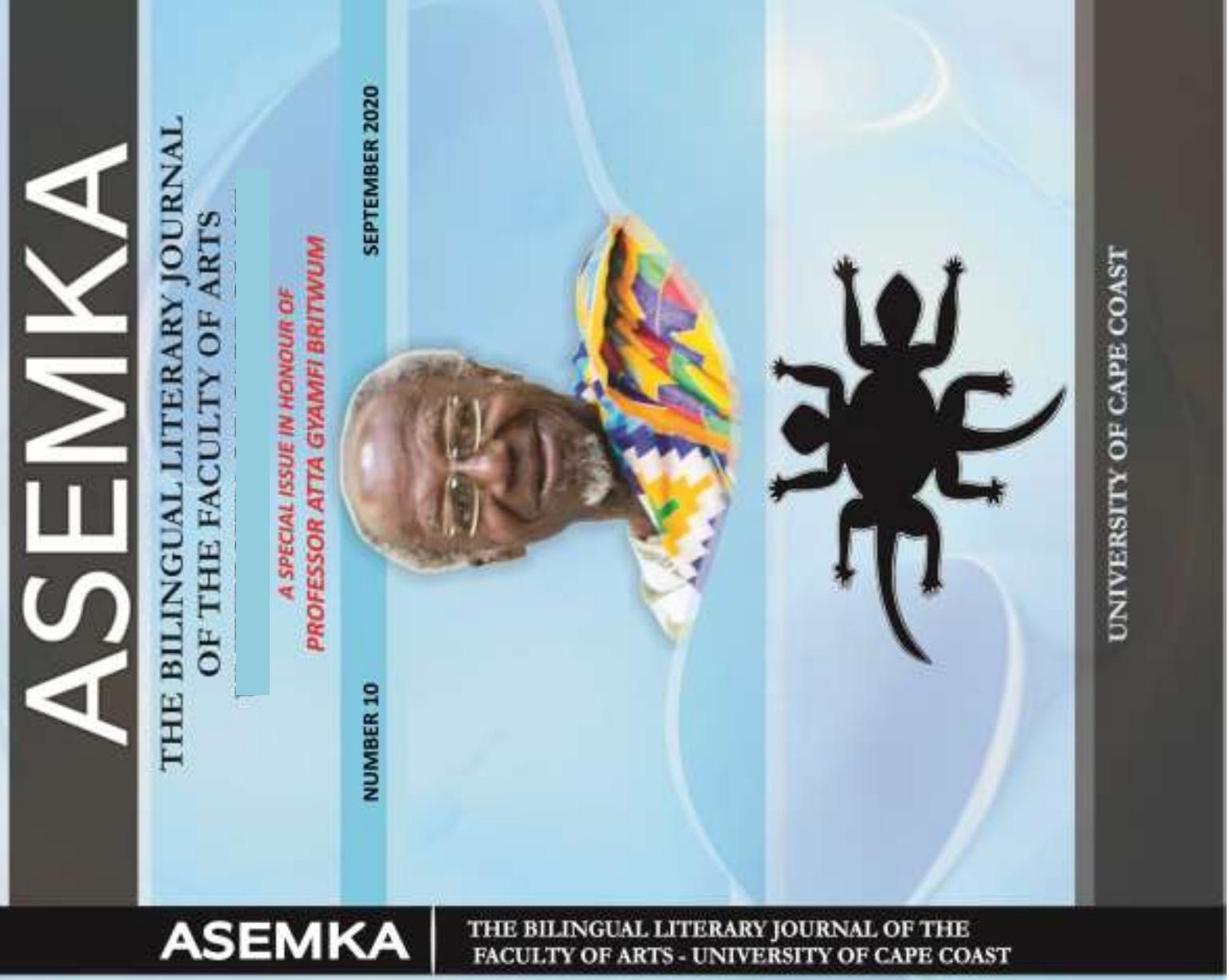





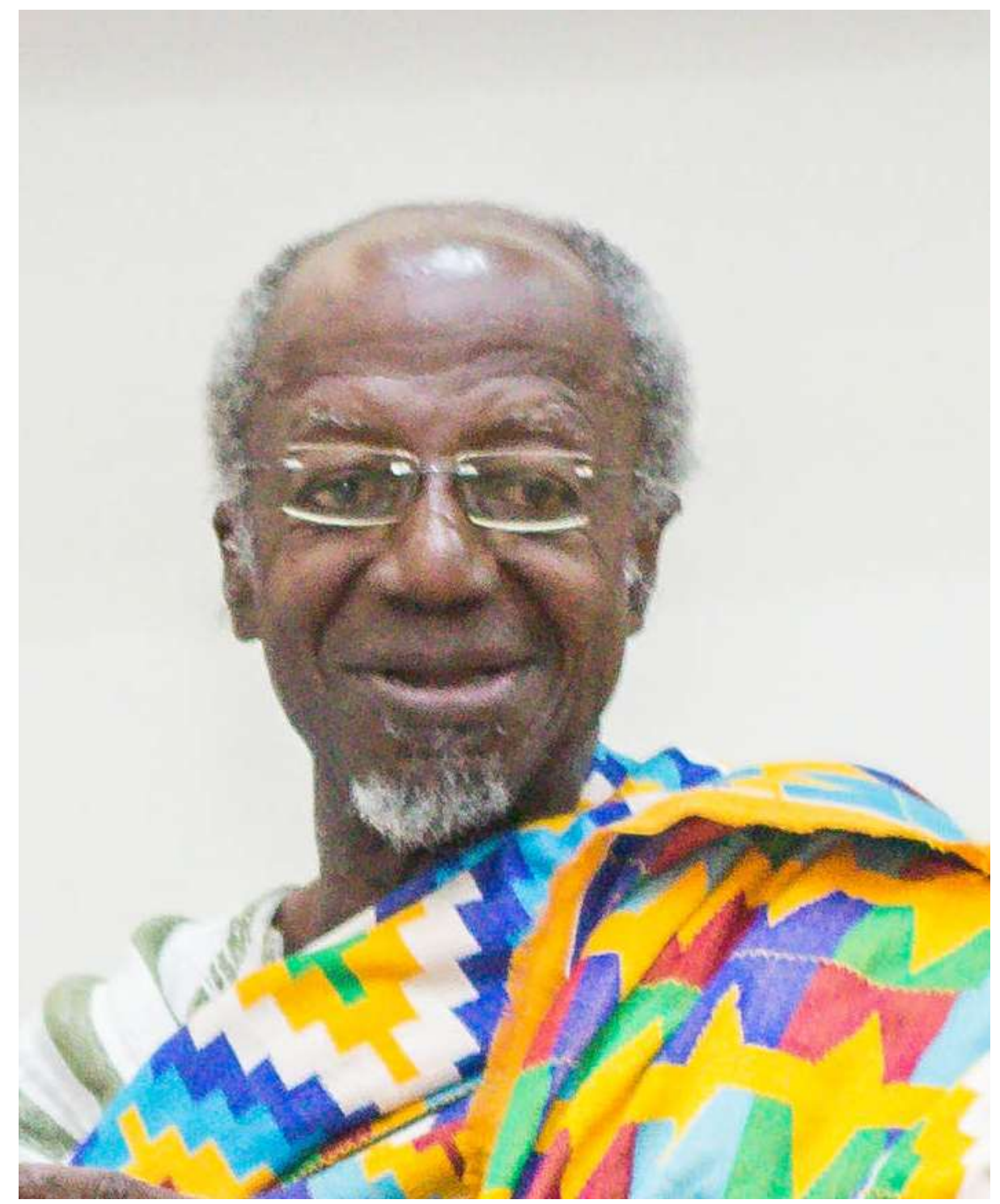

PROFESSOR ATTA GYAMFI BRITWUM 


\section{THE BILINGUAL LITERARY JOURNAL OF THE FACULTY OF ARTS UNIVERSITY OF CAPE COAST}

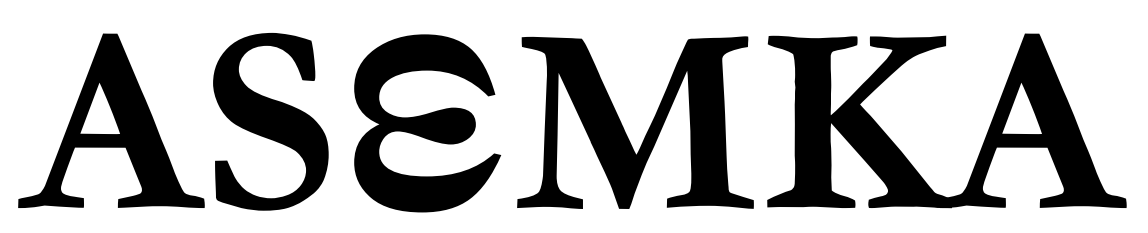

NUMBER 10

SEPTEMBER 2020

\section{EDITORIAL COMMITTEE}

Editor-in-Chief: Prof. Samuel Awuah-Nyamekye (Ph.D.)

Editor: $\quad$ Prof. Mawuloe Koffi Kodah (Ph.D.)

Associate Editors: Dr. Samuel Kwesi Nkansah

Dr. Mrs. Theresa Addai Munumkum

Dr. Isaac Mwinlaaru

Business Editor: Rev. Sr. Dr. Matilda Alice Nsiah

\section{EDITORIAL STAFF}

Mr. Stephen Owusu-Amoh

Mr. Isaac Kweku Grantson

\section{EDITORIAL ADVISORS}

Prof. Kwadwo Opoku-Agyemang, University of Cape Coast.

Prof. Joseph B. A. Afful, University of Cape Coast.

Prof. Raymond N. Osei, University of Cape Coast.

Prof. Richard V. Cudjoe, University of Cape Coast.

Prof. Victor K Yankah, University of Cape Coast.

Dr. Mousa Traore, University of Cape Coast. 


\section{ACKNOWLEDGEMENTS}

We acknowledge the contribution of the underlisted members of the Department of French who did preliminary editorial work on the papers:

Dr. Anthony Y.M. De-Souza (Chairman)

Prof. Raymond N. Osei

Prof. Mawuloe K. Kodah

Dr. Sylvester P. Krakue

Mr. Ofosu Addo-Danquah

Mr. Micheal Donkoh (Secretary)

\section{SUBSCRIPTION}

Assmka is published twice in the Academic year by the Faculty of Arts, University of Cape Coast. The annual out-of-Ghana subscription rate, including air-postage, is US\$29 for individuals, and US\$ 59 for institutions and libraries. Single issue rate for individuals is US\$18. Claims for copies not received must be made within three (3) months following an issue's publication. Correspondence should be addressed to:

The Editor, Assmka

Department of French

Faculty of Arts

College of Humanities and Legal Studies

University of Cape Coast

Cape Coast

Ghana, West Africa

Email: asemkajournal@ucc.edu.gh

\section{ADVERTISING}

Advertising rate, size specifications and related information are available upon request. Please, contact the General Editor for more information.

\section{SUBMISSIONS}

Assmka is an internationally-refereed journal of the Humanities. It publishes scholarly and imaginative articles in Literature, Language, and Culture generally, including, Orature, Film, Theatre, Music and Art. Essays, Interviews, Book Reviews, Poetry, Short Prose Fiction and Drama are welcome. Submitted manuscripts, in English and French, must be prepared in accordance with the most recent of APA or MLA style manual, where applicable. The author's identity and address may appear only on the cover- 
page and nowhere else within the submitted manuscript. All manuscripts should be submitted electronically through:

asemkajournal@ucc.edu.gh

Manuscript will be duly acknowledged within two (2) months of receiving them. Individuals whose works are accepted for publication may provide Assmka with a brief bio-data. The Editors cannot be held liable for lost or damaged manuscripts. Material published by Assmka does not necessarily represent the views of the Journal's Editors, Staff, Financial Supporters or the University of Cape Coast and its affiliates. These parties disavow any legal responsibility related to all submitted material.

\section{BACK ISSUES}

Back issues of Ascmka that are in stock may be ordered from the Editor at US\$20 per copy.

\section{GRANT SUPPORT}

Assmka is funded through grants from the Office of the Dean, Faculty of Arts; the Publications' Board; and the Office of the Vice-Chancellor, University of Cape Coast, Cape Coast, Ghana.

No part of this Journal may be reproduced, stored in a retrieval system, or transmitted in any manner whatsoever without express permission from the Editors, except in the case of brief quotations embodied in critical Articles and Reviews.

Copyright (C2020 by The Editors and The Faculty of Arts, University of Cape Coast. The cover and page design elements were inspired by the Adinkra symbols of Ghana. 


\section{DEDICATION \\ PROFESSOR ATTA GYAMFI BRITWUM}

Professor Britwum is a man of many parts. He is as much at home with Marxist Economic Theory and Feminist Sociological Thoughts, as he is with French and Francophone Literatures. He is a great teacher and Administrator of international acclaim. The Editors dedicate this special issue of Assmka to his honour. 


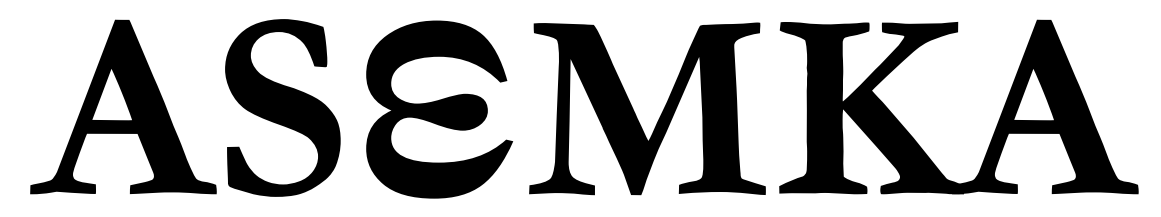

NUMBER 10

SEPTEMBER 2020 


\section{CONTENTS}

$\begin{array}{llll}\text { Editorial Committee } & \sim & \sim & \sim i i \\ \text { Editorial Staff } & \sim & \sim & \sim i i \\ \text { Editorial Advisors } & \sim & \sim & \sim i i \\ \text { Acknowledgements } & \sim & \sim & \sim i i i \\ \text { Subscription } & \sim & \sim & \sim i i i \\ \text { Advertising } & \sim & \sim & \sim i i i \\ \text { Submissions } & \sim & \sim & \sim i i i \\ \text { Back Issues } & \sim & \sim & \sim i v \\ \text { Grant Support } & \sim & \sim & \sim i v \\ \text { Dedication } \sim & \sim & \sim & \sim \\ \text { Foreword } \sim & \sim & \sim & \sim x \\ \text { Assmka: Editorial } & \sim & \sim & x i-x v i i\end{array}$

Articles

First Section - French

Britwum, A. G.

Insuffisances Théoriques Des Damnés De La Terre De

Frantz Fanon

$\sim$

$\sim 2-15$

Kodah, M. K.

Disculpation de Dieu dans le malheur des hommes:

Une lecture critique de Gouverneurs de la rosée de

Jacques Roumain $\sim \sim \sim 16-31$

Addo-Danquah, $O$.

Le récit de pensées: Une analyse comparative de Vol de nuit d'Antoine de Saint-Exupéry et La Condition humaine d'André Malraux

Kodah, M. K. \& Togoh, A. A. X.

Réactions des femmes face au conflit de genre dans C'est le soleil qui m'a brûlée et Tu t'appelleras Tanga de Calixthe Beyala

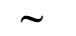

$\sim$

$\sim \quad 45-59$ 
Kudi, M. D.

La Littérature francophone face aux médias de télécommunication : Une nouvelle dynamique de la création romanesque, le cas de L'Énigme de retour et Tout bouge autour de moi de Dany Laferrière $\sim \quad$ 60-72

Gli, $M$.

Les faces du bonheur dans Vol de nuit d'Antoine de Saint-Exupéry $\sim \sim 73-85$

Krakue, S. P.

Christ haïtien : Gouverneurs de la rosée et La Bible $\sim 86-93$

Afari, E. S. K. \& Yegblemenawo, C. A. A.

Apports de la télésérie à l'amélioration de la compétence d'expression orale du FLE à l'école normale $\sim 94-116$

Bationo, J.-Cl.

Didactique de la littérature et littérature didactique:

l'exemple de la littérature africaine francophone en classe de langues étrangères au Burkina Faso

Second Section - English

Krakue, S. P.

Quod erat demonstrandum: A comparative study of narrative technique in Ama Ata Aidoo's Changes and Albert Camus'

Les justes (The Just Ones) 〜 $\sim$ $133-141$

Adjandeh, E. A.

Analysis of Wole Soyinka's Trials of Brother Jero in Relation to Ghanaian Religious Discourse

Sam, C. A.

Decolonizing the Postcolony: Of Men, Spatial Politics and the New Nation in WA Thiongo's Wizard of the Crow.

Kambou, M. K. \& Traore, S. A.

Manipulation and the popular uprising in Burkina Faso in 2014. $\sim \quad \sim 172-189$ 
De-Soura, A. Y.M.

Test-taking Strategies of University of Cape Coast Students of

French as a Foreign Language: a Case Study $\sim 191-216$

Kambou, M. K. \& Soma, L.

Local Culture and EFL Vocabulary Learning $\sim \quad 217-238$

Kabore, A. \& Nazortin, C.

Critical Analysis of the Place and Importance of Literature in the Teaching / Learning of English and in School Leaving Certificate Examination in Burkina Faso from 1985 to 2018

Malgoubri, I., Sawadogo, M. \& Kambou, M. K.

Digital Audio-visuals Aids and Listening in English as a

Foreign Language Classrooms

Osei, R. N. \& Inusah, $H$.

A Critique of the Images of Heaven in the Scriptures of the

Abrahamic Religions: An Existentialist Perspective $\sim$ 270- 282

Negedu, A. K.

Lexical Gaps and Ideological Shift in the Translation of

Chinua Achebe's Things Fall Apart as "Le Monde

S'effondre" in French $\sim \sim 283-297$

Talburt, $T$.

Political Transformation and Development in Africa:

Lessons from Achebe's Things Fall Apart

$\sim 298-313$ 


\section{FORWORD}

All the papers in this Volume were presented at a three-day Conference in honour of Professor Atta Gyamfi Britwum who turns eighty years in March 2021. Most of those years he spent at University of Cape Coast, having cut his teeth as a young lecturer in French language and Literature-in-French in 1974. After many years of an illustrious career in teaching, publication and extension, he bowed out at age seventy, but he didn't get the well-deserved rest he was entitled to; he continues to support his Department and the University as a whole. Today, Professor Britwum's name is associated with high standards of professionalism which earned him the nickname 'L'oracle'. Indeed, it is impossible to find another name universally acknowledged as embodying the excellence in French education offered at the Department of French, University of Cape Coast.

The decision to honour Professor Britwum couldn't have been taken at a more appropriate time. It was planned to coincide with the fiftieth anniversary of the publication of the Beautyful ones are not yet Born, Ayi Kwei Armah's first novel. Britwum never grew tired of reading, teaching and examining it. Such was his respect for Armah's craft. So, the three-day Conference was as much a celebration of Armah's contribution to the shaping of the African novel as it was a tribute to Professor Britwum's work as a teacher of literature of immense influence.

One only has to look at the titles of the papers published in this Volume to get an idea of how deep his influence runs at UCC and beyond. Most of the contributors once upon a time sat at the master's feet, but are now scholars in their own right keeping the flame of French scholarship burning bright (George Cooper: "Polished in a high degree, as each froggie ought to be/Now they sit on other logs, teaching other little frogs.") A good number of the papers are on Literature, nonetheless not limited to Armah's works. No Surprise there. Nevertheless, there are Language papers there too. No surprise here either, for the man to whose honour the Volume is dedicated is equally at home in both Language and Literature

\section{Lawrence $K$. Owusu-Ansah,}

Department of English, UCC.

A Disciple 


\section{$A S E M K A:$ EDITORIAL}

This Special Edition of $A S E M K A$, a bilingual literary journal of the University of Cape Coast, is published in honour of Prof. Atta Gyamfi Britwum, a revered Associate Professor of Francophone African Literature and Civilisation in the Department of French, U.C.C. It contains twenty (20) papers centred on diverse areas of teaching and research in the Humanities and on the theme of the Conference - Literature and the Humanities in the 21 Century: Interdisciplinary Perspectives - held in his honour by the Department of French, University of Cape Coast, Ghana, $13^{\text {th }}-15^{\text {th }}$ Mars, 2019. To reflect Prof. Britwum's area of research interest, the essays are arranged in two sections according to his dominant medium of instruction (French language) and speciality (Literature and Civilisation), followed by those in English language. The first section consists of a set of nine (9) essays in French spanning between themes in Literature and Language. The second section is made up of a set of eleven (11) essays in English which examine issues in literary studies, Language and Didactics, ICT and French Education, Philosophy, and Translation, among others. This special arrangement is however representative of the bilingual nature of the Journal.

\section{First Section}

Britwum, A. G.'s paper titled, “Insuffisances Théoriques Des Damnés De La Terre De Frantz Fanon", presents the Fanonian perspective as a complement to the African nationalism that informed anticolonial struggles. The study posits that African nationalism, populist in nature, for failing to target the capitalist economic base, which defines colonialism, ended up strengthening it. It concludes that Fanon's anticolonialist perspective, despite its overt radicalism, is not designed to allow a "bottom-to-top change" in colonial / capitalist society.

Kodah, M. K.'s paper titled, "Disculpation de Dieu dans le malheur des hommes: Une lecture critique de Gouverneurs de la rosée de Jacques Roumain", puts into question the responsibility of God in the suffering of men on earth and the capacity of man to make and unmake himself. The study aims at absolving God of the guilt of the miseries of men, and also questioning the atheistic or anti-religion denunciation of this narrative 
text since its publication. The study is accomplished through a critical reading and a thoughtful analysis of Jacques Roumain's Gouverneurs de la rosée within the analytical structure of literary studies and sociocriticism.

Addo-Danquah, O.'s paper, "Le récit de pensées : Une analyse comparative de Vol de nuit d'Antoine de Saint-Exupéry et La Condition humaine d'André Malraux", drawing inspirations from theorists such as Léon Edel (1961) and later Dorrit Cohn (1981), examines what Antoine de Saint-Exupéry's Vol de nuit by and André Malraux's La Condition bumaine respectively can offer on the side of representations of the interior life. The study is posited within the framework of narratological theories.

Kodah, M. K. \& Togoh Tchimavor, A. A. in "Réactions des femmes face au conflit de genre dans C'est le soleil qui m'a brûlée et Tu t'appelleras Tanga de Calixthe Beyala" examine the reactions of women to gender conflict in Calixthe Beyala's C'est le soleil qui m'a brulée and Tu t'appelleras Tanga. The study critically reflects on the various ways women in Beyala's C'est le soleil qui m'a brulée and Tu t'appelleras Tanga react to oppression and exploitation resulting from patriarchal domination. It therefore examines the sources and nature of this conflict, and how women react to it in the two novels. The study points to the fact that, much as conflict emanating from patriarchal oppression and male's domination in human societies is inimical to the rights of women, the methods used by the latter to free themselves from this state of being remain questionable, in that, these methods defy rational thinking and are also a kind of reversal oppression and domination which are equally unacceptable.

Kudi, M. D.’s paper, “La Littérature francophone face aux médias de télécommunication: Une nouvelle dynamique de la création romanesque, le cas de L'Énigme de retour et Tout bouge autour de moi de Dany Laferrière", seeks to examine how pertinent painting, photography, television, telephone etc. are to the production of the contemporary Francophone novel. The study focuses on L'Énigme de retour (2009) and Tout bouge autour de moi (2011). The analysis is based on the perspective of literary intermediality propounded by Jürgen E. Muller which is characterised by an interaction between telecommunication media and literary text. The study establishes through these selected novels that these media forms are not simply another form of expression in the novel but rather a lens through which the story is narrated. 
Gli, M.'s paper titled, "Les faces du bonheur dans Vol de nuit d'Antoine de Saint-Exupéry", analyses the faces of happiness in Antoine de Saint-Exupéry's Vol de Nuit. The study is conducted through thematic approach. This approach is complemented by Maslow's theory of human needs. The collection of data or the collection of information is purely documentary. The study therefore seeks to establish a link between individual happiness and collective happiness in Saint-Exupéry's selected narrative text.

Krakue, S. P.'s paper, “Christ haïtien : Gouverneurs de la rosée et La Bible", attempts to question Jacques Roumain's Gouverneurs de la rosée in order to elucidate the novelist's use of the biblical text in his creative activity. The study demonstrates that Jacques Roumain's narrative text turns out to borrow biblical ideas not only to develop his plot but also to design his main character.

Afari, E. S. K. \& Yegblemenawo, C. A. A. in “Apports de la télésérie à l'amélioration de la compétence d'expression orale du FLE à l'école normale." examine the impact examine the impact of the use of serial movies as teaching aid on oral expression of French language learners in Colleges of Education in Ghana with the aid of smartphones. The study discovers that the use of serial movies in teaching French boosts learners' performance in oral communication. It therefore recommends that serial movies could be used in teaching French language lessons in order to enhance the oral communication competencies among learners.

Bationo, J.-Cl.'s paper titled, "Didactique de la littérature et littérature didactique : l'exemple de la littérature africaine francophone en classe de langues étrangères au Burkina Faso", shows not only how to teach literature in language class but also how to use didactic literature to develop social skills among learners to reduce vandalism, school violence, negative stereotypes, misunderstandings of intercultural nature while cultivating social peace and living together in a context of internationalization, globalization and digital revolution. The paper focuses on francophone African Literature and posits that methodological approach used for the didactic transpositions of literary content is based on the new orientation and the redefinition of the objectives of language teaching and on the didactic models of the aesthetic reception of didactics of literature which requires putting the learner in intensive interaction with the text and motivating him/her to express himself/herself on his/her reading experiences. 


\section{SECOND SECTION - ENGLISH}

Krakue, S. P.'s paper titled, “Quod erat demonstrandum: A comparative study of narrative technique in Ama Ata Aidoo's Changes and Albert Camus' Les justes (The Just Ones)", demonstrates through textual analysis, how in Ama Ata Aidoo's Changes and Albert Camus Les justes, the authors resort to a specific form of irony to bring the discussion of issues raised to a conclusion. The technique consists in demonstrating clearly a huge discrepancy between a "fine" idea and its practical usefulness. Both authors successfully use narrative technique. Albert Camus demonstrates the hollowness of the idea of fighting for justice through revolutionary violence and Ama Ata Aidoo similarly demonstrates the fatuousness of the theory of women-emancipation-through-polygamy.

Adjandeh, E. A. analyses selected reports in Ghanaian media in relation to the clergy and identifies how Wole Soyinka's theme is reflected in these media in her paper titled, "Analysis of Wole Soyinka's Trials of Brother Jero in Relation to Ghanaian Religious Discourse". The study seeks to examine the extent to which themes in Soyinka's Trials of brother Jero play out in religious discourses in Ghana. The global nature of the issues problematized by Wole Soyinka also comes out through this study as the work set in Nigeria is analyzed in relation to the selected articles set in Ghana. The paper relies on a content analysis of Trials of Brother Jero and similar themes presented in the selected articles, and makes a few recommendations on how these religious issues could be partially, if not wholly, resolved in Ghana.

Sam, C. A.'s paper, "Decolonizing the Postcolony: Of Men, Spatial Politics and the New Nation in WA Thiongo's Wizard of the Crow", examines how Ngugi Wa Thiongo's Wizard of the Crow blatantly explores Africa's complicity in a seemingly cyclic colonization in the $21^{\text {st }}$ century and its attendant consequences for the total liberation of Postcolonial Africa. The study examines the correlation between masculine representations, spatial reorganization and futurity as alternative ways in thinking about Africa's future through Bakhtin's theory of the carnival and other such concepts as polyphony and the grotesque. The result of the analysis is that the correlation between forms of communities and forms of masculinities is an indication of a vision of hope for Postcolonial Africa. 
Kambou, M. K. \& Traore, S. A. in "Manipulation and the popular uprising in Burkina Faso in 2014", analyse the different discourses in the build-up to the popular uprising in Burkina Faso on the $30^{\text {th }}$ and $31^{\text {st }}$ October 2014. It attempts to clarify how political and civil society leaders use language and other non-linguistic elements to influence the ordinary citizens' minds and, indirectly, their actions. The analysis is premised on Van Dijk's (2006) Sociocognitive approach. The paper analyses the cognitive, the social and the discursive dimensions of manipulation in six political speeches (two speeches from Civil Society, two from the ruling party and two from the political opposition). The results suggest that the three groups manipulated their audiences, and finally, the ruling party lost following the resignation of the then Head of State, making way for a Transition government to take over the reins of governance.

De-Souza, A. Y. M.'s paper “'Test-taking Strategies of University of Cape Coast Students of French as a Foreign Language: a Case Study.” seeks to provide a description of test-taking strategies that may inform teaching and learning of French for better output in tests against the background that Ghanaian students of French as a foreign language deploy strategies that are not adequate enough in answering test items in French. The study examines data gathered right after a French test by level 200 students, using recollective verbalization protocols.

Kambou, M. K. \& Soma, L. examine in their paper titled, "Local Culture and EFL Vocabulary Learning”, the influence of learners' culture on foreign language vocabulary. The paper seeks to demonstrate that there is a link between culture and lexico-semantic errors committed by learners of English as a foreign language among Dioula speaking students in Burkina Faso. A language test composed of two written activities was used as the data collection instrument. The results revealed that the Dioula speakers' English is influenced by their culture. These results have some pedagogical implications. They, therefore, suggest that we adapt the teaching of EFL vocabulary to learners' culture.

Kabore, A. \& Nazortin, C. in "Critical Analysis of the Place and Importance of Literature in the Teaching / Learning of English and in School Leaving Certificate Examination in Burkina Faso from 1985 to 2018", analyse the types of texts given at the "Baccalaureate A" written examination in the last thirty years. In this study, quantitative and qualitative 
data are collected. Baccalaureate written English papers are the main focus of our collection. Teachers and supervisors are interviewed. The study is grounded on "Reader-Response Theory" which stresses the interactions between the reader and the text. The results of the study show that the great majority of texts proposed for "Baccalaureate A" examination, in the last thirty years, are non-literary texts.

Malgoubri, I., Sawadogo, M. \& Kambou, M. K.’s paper titled, “Digital Audio-visuals Aids and Listening in English as a Foreign Language Classrooms", is an experimental study which investigates the potential of digital audio-visuals to improve the listening skills of EFL learners in secondary schools in Burkina Faso. On the assumption that learners born around the year 2000 are digital natives, the researchers try integrating smartphone-friendly audio-visuals in their EFL classrooms in a four-week experiment involving one Experimental Group and one Control Group. The experiment aims at gauging the effectiveness of those aids operated via students' smartphones in improving learners' listening and speaking skills. Independent T-tests were used to compare the groups and Sample Paired TTests to make comparisons within groups. The study suggests that, if appropriately used, smartphones are excellent devices for language teachers and learners in this digitizing world.

Osei, R. N. \& Inusah, H.'s paper, “A Critique of the Images of Heaven in the Scriptures of the Abrahamic Religions: An Existentialist Perspective." Critically examines the scriptural images of heaven as captured in the Abrahamic religions - Judaism, Christianity and Islam - from the existentialist perspective. The paper argues that the idea of life beyond this earthly existence for all human beings in a specially prepared location by God for eternal happiness for those who obey His commands on earth called Heaven, as propounded by the Abrahamic Religions, throws up a lot of problems, especially from the existentialist perspective. The study concludes that the scriptures' constructs of heaven appear self-contradictory and fail to strike a chord with the contemporary image of the ideal society when perused from the existentialist perspective and should, therefore, be discarded.

Negedu, A. K.'s paper "Lexical Gaps and Ideological Shift in the Translation of Chinua Achebe's Things Fall Apart as "Le Monde S'effondre" in French." examines the ideological divergence between the title of the original text and the title of the translation, following an observation 
that in translating Chinua Achebe's Things Fall Apart, Michel Ligny translates directly Igbo terminologies, realities and beliefs into the French language. The paper concludes that the ideology that the translated title projects to French-readers is totally different from the ideology that the original title projects to English-readers.

Talburt, T., in "Political Transformation and Development in Africa: Lessons from Achebe's Things Fall Apart", formulates critical perspectives on the significance of Achebe's novel for the socio-political and economic transformation and development of the African continent. The paper challenges one of the central assumptions in this story that Africa falls apart as soon as it comes in contact with Europe. It questions aspects of political conservatism exhibited in Okonkwo who is suspicious of fundamental changes to his society. The discussion is based on the jollof rice principle of political hybridisation of development which proposes the amalgamation of Westernised and non-Western ideas and systems, in order to achieve economic development, rather than totally rejecting Westernisation in its entirety. The study uses examples of Western-style democracy and State intervention in Africa to demonstrate the significance of embracing some aspects of Westernisation through political hybridisation. 




\title{
Political Transformation and Development in Africa: Lessons from Achebe's Things Fall Apart.
}

\author{
Tony Talburt \\ University of Cape Coast, Cape Coast, Ghana.
}

\begin{abstract}
Drawing upon Achebe's classic work, Things Fall Apart, where Okonkwo, the principal character, refuses to accept intrusions or changes influenced by Westernisation, this paper challenges one of the central assumptions in this story, that Africa falls apart as soon as it comes in contact with Europe. Notwithstanding the overwhelmingly negative effects of the trans-Atlantic slavery systems and European colonialism on Africa (and its Diaspora), this study argues, that to a large extent, Africa's economic transformation and development could be greatly enhanced by adopting some new ideas and systems from within as well as outside the continent. This paper questions aspects of political conservatism exhibited in Okonkwo who is suspicious of fundamental changes to his society. The discussion is based on the jollof-rice principle of political hybridisation of development which proposes the amalgamation of Westernised and non-Western ideas and systems, in order to achieve economic development, rather than totally rejecting Westernisation in its entirety. The jollof-rice principle of political hybridisation is based on the idea of blending systems and ideas in much the same way that rice and tomato are combined in West Africa, to create jollof-rice. This study uses the academic discipline of international political economy in its analysis of themes of political conservatism and development in Africa, as portrayed in the Achebe's work. In contrast to Okonkwo's political conservatism, this study uses examples of Western-style democracy and state intervention in Africa to demonstrate the significance of embracing some aspects of Westernisation through political hybridisation.
\end{abstract}

Keywords: African Development; jollof-rice principle of development; political conservatism; political hybridisation. 


\section{Introduction}

In Chinua Achebe's classic work, Things Fall Apart (1986), Okonkwo, the principal character, refuses to accept ideas or systems based upon Westernisation which begins to take root in his village in Africa. He is determined to ensure the preservation of the existing status quo. Okonkwo, therefore, is regarded in this study, as a representation of a political conservative, who is resistant and suspicious of fundamental changes in society. It is the issue of conservatism and its broader links to economic development that forms the basis of this study. The study seeks to challenge this conservative approach and one of its underpinning assumptions in this story, which is that 'Africa falls apart as soon as it comes in contact with Europe'. Notwithstanding the overwhelmingly negative effects of the transAtlantic slavery and European colonialism on Africa's development, the central proposition of this work is that, to a large extent, economic development in Africa could be greatly enhanced by embracing the best of ideas and systems from within, as well as outside the continent. Therefore, drawing upon what is described here as the 'jollof-rice' principle of political hybridisation, this study suggests that African governments, in keeping with previous Far-East, Arabic and more recently, Western civilisations, need to adopt unique hybridisation of ideas and systems, to enhance the development of their people. More specifically, rather than rejecting aspects of Western ideas and systems in their entirety, as Okonkwo campaigns for in the story, this study suggests the need for a hybrid approach, in much the same way that rice and tomato, originally from different parts of the world, were combined in West Africa to create jollof-rice. The study first provides an overview the jollof-rice principle of political hybridisation, before examining specific examples of its application in a few African countries.

Achebe' classic work, Things Fall Apart (1986) can be regarded as a tragic account of an African society's destruction and destabilisation that occurs once it comes into contact with European missionaries and colonialists. This idea of the destructive nature of European colonisation on African society is perhaps best captured in the story by the quote: 'The White man has put a knife on the things that hold us together and we have fallen apart' (Achebe, 1986: 127). A number of reviewers have also discussed this novel as an example of the nineteenth century colonial disintegration of this Igbo society of Umuofia (Mongredien, 2010; The New Times, 2010). This is indeed a story of a clash between those wishing to retain African indigenous cultures, and those espousing Westernisation.

The central character in this story is Okonkwo, who is driven by the twofold desire to avoid replicating the miserable failure of his father in his own 
life, and secondly, and more important for this study, is his determination to achieve success through hard work as well as by maintaining the local traditions. This popular local hero, the greatest wrestler and warrior among the nine villages of Umuofia, fears only one thing, and that is failure itself (Achebe, 1986). Okonkwo can be seen as the main person who consistently tries his best to maintain the customs and traditions of Umuofia. Okonkwo, in this sense, displays all the main features associated with political conservatism. This ideology, is based on what Heywood (2015) describes as a desire to conserve, as well as to resist or demonstrate scepticism towards change. Two key features of political conservatism are: maintaining traditions and also the ultimate respect for the established authorities.

Okonkwo, therefore, in common with the Luddites of England and also the British landed aristocracy in the early nineteenth century, are conservatives who strongly oppose societal changes. Burke (1999), who wrote in 1790, is regarded as one of the founders of modern conservative thought, similarly opposes major societal changes taking place in France during the French Revolution of the late 1780s and early 1790s. He claims, for example, that 'kings should not owe their crown to the choice of the people' (Burke, 1999: 14-15). In other words, ultimate power should be held by the monarchs, and the populace should be totally subject to them. As far as he is concerned, 'the king is not there to obey us, but we are to obey the law in him' (Burke, 1999: 29). Whereas the people making up the Third Estate in Revolutionary France, are demanding political, economic and social changes, Burke is vehemently opposed to this, and insists on the preservation of the old order, based on the divine rights of the monarchy. Unlike the case in France where the agents of change were the people themselves, in the African society where Okonkwo lived, it is the European missionaries and colonisers who seek to implement changes. In both cases, however, despite the source from which the change derives, those with authority and privileges prefer to conserve the traditional order. Okonkwo, therefore strives to ensure the values, systems and culture of his society are preserved at all costs.

Not everyone in Umuofia, however, feels the same way as Okonkwo about the arrival of the Europeans. Okonkwo's friend Obierika, inwardly and silently, questions some of cultural practices in Umuofia such as: why Okonkwo should have been banished from the village and his entire compound burned down because of an accident. In addition, he questioned why he has to throw away his wife's twins because of obedience to local customs or traditions (Achebe, 1986: 89). Okonkwo's own son is drawn to the new Christian religion, partly because of the key questions his cultural traditions cannot answer. One of these issues is the killing of twins, once they were born (Achebe, 1986: 109). Furthermore, the Europeans have built a 
'trading store, and for the first time, palm oil and kernel became things of great price, and money flowed unto Umuofia (Achebe, 1986: 128). Here, as is discussed below, we see an example of the paradox of destruction and reconstruction that often accompanies economic development and change. In this sense, therefore, this African society is torn between two extreme positions of either totally rejecting Western ideas and systems, or being completely overtaken by them. These are clashed between political conservatism and reformers, or between africanisation versus Westernisation. Even though pan-Africanist writers such as Rodney (1988) and Diop (1974) warn of the exploitative nature of European political and economic engagement with Africa, what is being argued here, is for countries to consider adopting some of the new ideas and systems from the West and blending these with their own, to create something new.

\section{The jollof-rice principle of political hybridisation and economic development}

The jollof-rice principle asserts that appropriate and careful embracing, adaptation and use of new ideas, systems, cultures and achievements are necessary for a country to achieve structural transformation and development. This broad idea is based on the origin and manner of the creation of the West African meal of jollof-rice. This particular meal is only made possible because of the unique blend of two essential ingredients of rice and tomato, from two very different parts of the world. Rice, whether originally from the Far-East or the African variety, and tomatoes from South and Central America, are both blended during the colonial period to create an African meal. From the creation of jollof-rice, probably from Senegal, in West Africa, two important lessons are worth noting, that are applied in the succeeding discussion below, with regard to economic development in Africa. Firstly, as a result of European colonialism, Africa has been introduced or exposed to tomatoes which have not been rejected. Secondly, over a period of time, tomato has been blended and cooked with rice thereby creating a new hybridised African meal. This study builds upon the particular idea of the hybridisation of rice and tomato to create jollof-rice, by postulating that the correct balance and combination of different development ideologies and policies help to enhance structural transformation and development in every human society. Okonkwo's natural conservatism results in his resistance to the introduction of Western-based new systems that seek to undermine or threaten his worldview. This study, however, claims that for economic development to occur, some degree of exposure to, and adaptation of new ways of operating, is crucial in order for transformation and development to occur. 
There are two key phases involved in the jollof-rice principle. The first phase consists of the initial exposure and eventual acceptance of new ideas, while the second phase comprises the incorporation and hybridisation, resulting in change and development. During the first phase of initial exposure, countries are brought into contact with new cultures, ideas, systems and technologies. These forms of initial exposure, have in the past, been influenced principally by international commerce and trade, wars, conquests and settlements in foreign countries, and also through education or cultural exchanges. Through some of these means, different societies are brought into contact with one another each, though obviously, not always for altruistic reasons, as the example of Western colonisation of Africa demonstrates. The second phase of this jollof-rice principle focuses on the utilisation and incorporation of these new ideas, cultures and systems into society in order to bring about some degree of transformational change or development. It is primarily the second phase of this principle that forms the main basis of this study.

It is through such measures that other civilisations are able to make significant strides forward resulting in substantial transformation and development. From the late Middle-Ages, much of Western civilisation was initially exposed to, and later influenced by, similar patterns of exposure to systems, ideas, customs, and scientific and technological achievements from non-Western countries, particularly the Arab world. Himmelstrand et al (1994) opine that in order for Europeans to have achieved global advantage and eventual domination, they had to first be exposed to ideas and skills through interaction with Arab sailors and traders, through whom they acquired some knowledge in the area of ship-building and the related wood technology.

Stuenkel (2017) makes a similar point, asserting that the rise of Western Europe and its subsequent Western-centrism was partially brought about by the impact of Islam and Arabic contributions. Astronomy, Algebra, Trigonometry, and the decimal system, were transmitted to them, mainly by Muslim scholars in Spain (Stuenkel, 2017: 44). Some of these innovations occurred as a result of Arab and North African conquests in parts of southern Europe in the Middle-Ages. Despite the fact that much of Africa's integration in the modern global order has been based on European expansion and exploitation, McCarthy (1994) argues that Africans have been nonetheless forced to incorporate aspects of political, economic and socio-cultural changes. Parts of Western Europe were colonised and exploited by Arabs and African Moors, before later becoming colonisers of much of the modern world. Through such interchanges, commerce and travel, much of Western Europe was able to incorporate these changes in order to achieve substantial transformation and development, through a combination of delicate balancing 
of competing ideas and systems. In fact, Diop (1974) claims that, the roots of Western civilisation go back much earlier to ancient Egyptian origins. The key point, however, is that it was only through Western Europe's initial exposure to other societies that they have been able to demonstrate this first key phase of the jollof-rice principle, where countries use diverse views, skills, experiences and lessons from elsewhere for their own development.

In most societies where the elites or the powerful exist, they tend to be the main group that benefits from the maintenance of the existing status quo. Okonkwo best symbolises this in Things Fall Apart. He represents the traditional conservative class that is happy to continue with the existing order and fears changes because this would result in it losing control and power over the society. It is the traditional and conservatives like the Luddites in Britain and the Okonkwo (ites) in Africa, who generally resist structural transformation and new developments. It is only when these initial fears, suspicions and opposition to change are overcome, that the second phase of the jollof-rice principle, of hybridisation and development can occur.

Because the main theme in Achebe's work centres on the clashes between two groups over the way their society should develop, the concept of economic development needs to be briefly explained. Ayittey (2005) claims that development should not only mean a change, but also how countries use their 'existing so called primitive, backward and archaic' institutions to generate economic prosperity' (Ayittey, 2005: 89). McCarthy (1994) also views development as a process involving change, but questioned whether this should always be at the expense of 'other people changing in order to adopt the values and norms of modern, Western society' (McCarthy, 1994: 23). Rist defines development as a set of practices for the reproduction of society and transformation designed to increase the production of commodities through the use of exchange (Rist, 1997: 13). Central to these definitions of development, therefore, is the idea of transformation or change. Remaining at the same level century after century, does not signify that significant economic development is taking place. According to McCarthy, societies should believe in the notion of change or human progress in which life will not necessarily be the same as it was last year, but should continually get better (McCarthy, 1994: 25-26). To resist changes, because it comes from outside one's own culture without first considering its value or relevance, could prevent or hinder one's development.

The general pattern of economic development in post-war SubSaharan Africa has oscillated between two broad sets of policies and theoretical positions, usually through the adoption of one strategy at the exclusion of the other, thereby avoiding a hybridisation approach. One dominant or popular post war position or development strategy adopted by 
many African States was partly inspired by anti-colonial, anti-capitalist rhetoric, with strong state-centric models based either on nationalistic, or socialist/marxist perspectives. The second development position adopted by African states was the market-centric liberal approach based on the pursuit of individualism and the limited intervention on the part of governments. In other words, countries opted for an 'either or' approach between these two broad development positions (Fofack, 2015), rather than embracing a more hybrid approach.

The central feature of the jollof-rice principle of political hybridisation is the significance of combining Western and non-Western ideas and systems in order to create forms of development that is best suited to conditions in Africa. Conservative leaders and elites such as Okonkwo in the story and Burke (1999), are often reluctant to embrace too many Westernised ideas that might undermine the established order. However, in the last three decades we have begun to witness significant economic successes in some African countries based on this broad principle of blending Western and non-Western ideas and systems. The first example of this can be seen with regard to the issue of liberal democracy and development in Africa and the second example centres on the significance of state intervention and development.

\section{Political hybridisation and democracy in Africa}

The pursuit of liberal democracy is fraught with difficulties arising partly from the variations in interpretations related to this concept. Some of the key features of Western-based liberal democracy include; representative, accountable and transparent forms of governments, regular fair systems of general elections, individual freedoms, a plural society where diverse opinions, pressure groups and political parties can co-exist, and respect for the rule of law. However, there is no one perfect model of democracy to which all countries can, or should attempt to fit into. Potter (2000), refers to three major kinds of political regimes in modern societies, consisting of liberal democracies, partial democracies and authoritarian regimes. Potter (2000) however, also makes reference to a mixed type of political regime in which the accountability of government to its citizens is qualified, and where military, traditional, and other unelected establishments, interfere with the electoral process and compromise the authority of the elected government. What this means, is that, whilst there might be a semblance of democracy through elections, only certain candidates tend to be elected. There may also be some degree of restrictions on the rights of freedom of speech, or independent groups may exist, but are closely monitored by the state (Potter, 2000: 367). 
Yoder (2013), in his study of democratisation in Liberia, Sierra Leone and the Democratic Republic of the Congo, referred to at least five different levels or types of democratic regimes. The first type of democracy is what he calls Deep democracy which is where the will of all the people are enforced. This would represent the 'purest' form of liberal democracy, while the fifth type was called anarchy where there was little or no democracy and a complete breakdown of central governance, for example in Somalia. Many African countries, therefore, fall between these two levels or extremes, meaning that they like vast majority of nation-states the world over, exhibit varying degrees of democracy. Furthermore, these variations of democracy may not all conform to the ideals of Westernisation or liberal democracy.

In the early 1980s, a number of African countries embarked on development paths that were based on unique blends of different levels or aspects of Western liberal democracy. For example, Kenya, Cote d'Ivoire, Cameroon, Gabon, Malawi and Swaziland were amongst Africa's most economically successful countries up to the early 1980s, yet all six were stable single party states and managed to control political disturbances when they occurred (McCarthy, 1994: 103). The causes behind these relatively short-term signs of economic successes in these African countries up to the 1980s were very much influenced by strong government interventionist policies with less than perfect democratic systems (McCarthy, 1994: 162). According to Potter (2000) In Uganda under President Yoweri Museveni and his National Resistance movement (NRM), three elections were held between 1986 and 1996, which, according to local and foreign observes, were free, fair and open. Yet, no opposition political parties were allowed to challenge the main political party, in what became known as a system of 'no party democracy.' Due to the level of political stability that prevailed in the country during from the mid1980s through the mid-1990s, the British Labour government even decided to accept this form of democracy and refused to push for multiparty reforms in Uganda (Kasfir, 1998).

Similarly in Rwanda, after the genocide of 1994, the president introduced the traditional Gacaca system of justice rather than a Westernstyled democratic judicial system whereby perpetuators of the genocide could give their side of the story and ask for forgiveness. According to Fairbanks (2012) the National University of Rwanda found that the vast majority of people said this system was far better than any other form of justice. Since the 2000s the state has been the main player in determining what, where and how much is to be produced in the agricultural sector. The state is the main driving force behind high-value services and high-end tourism and also modern urban planning (World Bank, 2019, p. 13). This World Bank Report also claims that whilst recognising the need for a strong interventionist state soon after the 
genocide, there could be consequences for private firms and their competitiveness should this continue to the norm (World Bank, 2019: 37).

Botswana is an excellent example of a country where they insisted on an economic development strategy that mixed aspects of their own African indigenous political systems with Western models. Since the country gained political independence in 1966, through its diamond exports and a stable political system, the country has achieved remarkable economic accomplishments. According to a study by Siwawa-Ndai (1997: 343) Botswana was the fastest growing economy in the world between the years 1970-1993. Interestingly enough, the Botswana Democratic Party (BDP), formed in 1962, had, from its inception, a support base of teachers, civil servants and traditional chiefs (Acemoglu, Johnson and Robinson, 2001) and has managed to rule continuously from the mid-1960s, winning all of the eleven general elections held since 1965 until 2014. The other political parties have been unable to gain significant political foothold on power. The idea of one-party rulership, even if based on internationally observed, democratically held elections, still sits uneasy in terms of typical Western-styled system of elections. What is even more remarkable is the significance of their chieftaincy system which is this blend of the 'modern and the traditional which combines elements of continuity with elements of change' (Mohamed Salih, 2001: 162). Botswana is one of the very few African countries where there is a House of Chiefs which is a large fifteen-member body, made up of chiefs from the main tribes, that serves as an advisory body to the main Parliament (Mohamed Salih, 2001).

Ali Mazrui (cited in Ostergard et al, 2004) also supports this point of a more Afri-centirc focus in terms of democracy, when he argues that in many African countries, representativeness is often measured ethnically rather than electorally. A government is deemed to be more or less representative to the extent that it reflects the ethnic composition of the wider society. In addition, African indigenous society is based on collectivism rather than individualism. In this sense, therefore, the 'notion of individual rights is foreign to African ethnophilosophy' (McCarthy, 1994: 107). These examples help to demonstrate, that, rather than engaging in campaigns of total resistance to Western ideas and system, or rejecting fundamental changes in society, where it is appropriate, some African countries can establish political systems best suited to their needs in even if they run counter to Western orthodoxy. This idea is equally applicable to the issue of State-intervention in the economy. 


\section{Political hybridisation and state intervention in African development}

The classic Westernised approach to state intervention in the economy within a market-centric liberal economy, is normally treated with suspicion and as un-necessary interference. Some African countries have been showing that they can adopt aspects of Westernised theories of economic development by embracing state-centric policies within a laissez-faire liberal framework.

In fact, Mehmet (19990 suggests that sound theories of economic development need to be grounded in culture-specific reality and constructed with open minds to learn about cross-cultural values, institutions and environments before prescribing policy interventions. One of the flaws Mehmet saw in Westernisation was the failure of the mainstream classical liberal theorists to see the inherent contradiction between the idealism of rationalism and the mercantilism of the profit motive (Mehmet, 1999: 6). Killick (1989) also propounded similar sentiments about the supposed superiority of the state in development planning within developing countries. After pointing out that the dividing line between the roles of the public sector and the private sector is often cloudy, he further opines, that, even in Western countries where large-scale changes were needed fairly quickly, such as the conversion of a peace to a war economy, this could not be left solely to a market economy (Killick, 1989: 62). He warned of the temptation of exaggerating the appropriateness of policy prescriptions derived from mainstream theories, and urged the 'avoidance of simplistic and single-solution responses to complex problems and economic systems' (Killick, 1989: 63). Pillay (2002) considers the role of the State in economic development in two ways; the first being a 'facilitative role' and the second being a 'directive interventionist' role. Singapore, South Korea and Taiwan are examples of countries where the directive interventionist role of the state was clearly visible. With specific reference to Africa, this directive interventionist approach is also suggested by W. Arthur Lewis (1967), who recommends that public ownership and operation of industrial undertakings in African countries should be done especially in cases of public utilities and also for purposes where there are young or infant pioneering industries (Lewis, 1967: 21-22).

Mauritius serves as a good example of an African state that is embracing this hybrid approach, by incorporating changes in their economic structure in order to enhance their development. Although its economy was once based largely on sugar production that accounted for $90 \%$ of its export earnings in 1970 , by 2000 , sugar accounted for $20 \%$ of its exports and manufactured goods accounted for 70\% (Pillay, 2002: 8). It is the state that played the leading role in this transformation, through its development of the 
Export Processing Zone (EPZ) and the development of the services sector around the financial and tourism sectors. The government is also working on upskilling the labour force especially in the knowledge-based economy. The EPZs were designed, subsidised and guided by the state and by the early 1990 s over 600 were employing 90, 000 worker or nearly a third of the island's work force (Meisenhelder, 1997: 290). He further concludes that economic growth of Mauritius up to the 1990s has been the result of the guidance and intervention of the state bureaucracy rather than the unfettered market place.

In Botswana, even though the World Bank (World Bank, 2018) recognised the economic success of within the country, measured in terms of its growth rate of $5 \%$ over the last decade, this institution is still pessimistic about the country's future economic prospect, because it was deemed to be too state dependent. The problem for the World Bank is that developing countries like Botswana, are not following the traditional market-centric approach, but have adopted a hybrid alternative. Goalathe, (1997: 48)) further attests to the fact that as early as the 1980s, the boom that occurred in Botswana was due in part to substantial government intervention, where state expenditure and net lending exceeded 30\% of GDP throughout the 1980s. Goalathe (1997) further opines that although the government policy was driven by laissez-faire economics, it also clearly recognised market fragilities and weaknesses, and therefore adopted a pragmatic approach to industrial development involving appropriate state intervention. One of the most significant of these was the government's Financial Assistance Policy (FAP), introduced in 1982 to provide financial support through grants and loans to up and coming private enterprises.

Dr Akinwumi Adesina, President of the African Development Bank group, recently made a statement pointing out that 'state-intervention is crucial to drive Africa's industrialisation in order for it to become a centre for trade and manufacturing' (Adesina, 2018). He further explains that Africa could learn a lot from the South Korea example, where their economic success was achieved by the right 'vision, creativity, ingenuity, fiscal discipline and willingness to make hard decisions in order to secure its future' (Adesina, 2018). Furthermore, writers such as Chang (2005) and Shutt (1985) claim that the industrially developed countries did not get where they are through the adoption of policies and institutions that they recommend to developing countries today.

Ajakaiye and Afeikhena (2014) have made the case for a hybrid approach quite aptly by suggesting that:

in view of the success of the emerging markets, particularly those of the EAP region, in implementing a judicious and 
pragmatic combination of government intervention and market mechanisms in the process of economic growth and structural transformation, and the spate of significant government interventions in the OECD countries in dealing with the ongoing economic and financial crisis, Africa should find support for a judicious and pragmatic combination of government intervention and market mechanisms as a strategy for achieving the inclusive, poverty-reducing, and equitable growth and structural transformation that has so far proved elusive (Ajakaiye and Afeikhena, 2014: 746).

Whereas political conservatives such as Okonkwo reject Westernisation in order to preserve the existing traditions, the evidence from these emerging African countries highlights the significance of incorporating aspects of Western ideas and systems in their own development strategies.

\section{Conclusion}

Two key points emerge from the forgoing analysis. The first, in contrast to the political conservative position of Okonkwo in Things Fall Apart, is that, in order for societies to experience transformation and development, some exposure to, and adoption of, new ideas and systems is inevitable. Even though the manner in which some of these exposures was brought about were often associated with European colonialism, trade and slavery, other methods such as commerce and trade or migration are also part of this process. Some African countries have begun to embrace or incorporate economic development ideas that would normally be contradictory to each other, and garner these to their own advantage. This has enabled them to achieve substantial levels of transformation and development. The two phases of the jollof-rice principle are not only inter-related, but crucial if transformation and development are to occur.

The second point which the study makes is to challenge the assumption, in Things Fall Apart, that the adoption of Western ideas leads inevitably to the destruction and retardation of societies. What is important here, is not the wholesale continuation of traditions or the total rejection of the new, but the appropriate blending and hybridisation of these, which is at the heart of the jollof-rice principle. A few countries in Africa have not been content to accept the conservative position that all things must continue as they always have, but have move towards development pathways based on the adoption and hybridisation of aspects of Westernisation as well as nonWestern approaches. Countries like Botswana, Mauritius and Rwanda, 
demonstrate that the wholesale copying or total rejection of Western systems of liberal or deep democracy, as well as non-state intervention in their economies, might not necessarily be the answer for achieving economic development. In contrast to Okonkwo's thinking, as well as conservatives in general, this study argues that, the adoption of new ideas and systems from elsewhere plays significant roles in achieving transformation and development.

\section{References}

Acemoglu, D., \& Robinson, J. (2013). Why Nations Fail: The Origins of Power, Prosperity and Poverty. London: Profile Books Ltd.

Acemoglu, D., Johnson, S., and Robinson, J. (2001). An African Success Story: Botswana. https://economics.mit.edu/files/284 Accessed 15 February 2019.

Achebe, C. (1986). Things Fall Apart. Oxford, UK and Portsmouth, NH, USA: Heinemann Educational Publishers.

Adesina, A. (2018). State Intervention Vital to Drive Africa's Industrialisation in Ghana Business News, 21 May, https://www.ghanabusinessnews. $\mathrm{com} / 2018 / 05 / 21 /$ state-intervention-vital-to-drive-africasindustrialization-adesina/ Accessed 17 February 2019.

Ajakaiye, O., and Afeikhena J. (2014). Economic Development: The Experiences of Sub Saharan Africa, in Currie Alder, Bruce. et al., International Development: Ideas, Experience, and Prospect. Oxford University Press: pp.733-747.

Ayittey, G. (2005). Africa Unchained: The Blueprint for Africa's Future, New York and Hampshire, England: Palgrave Macmillan.

Burke, E. (1999). Reflections on the Revolution in France, Oxford: Oxford University Press.

Chang, H. (2005). Kicking Away the Ladder: Development Strategy in Historical Perspective, London: Anthem Press.

Diop, C. A. (1974). The African Origin of Civilization; Myth or Reality, Chicago, Illinois: Lawrence Hill Books.

Fairbanks, M. (2012). Rwanda is not an Authoritarian Regime The New York Times, 19 September, https://www.nytimes.com/roomfordebate/ 
2012/09/19/autocratic-leaders-who-improve-their-countries/rwanda is-not-an-authoritarian-regime Accessed 20 April 2019.

Fofack, H. (2015). The Idea of Economic Development: Views from Africa, in Mongu, C., and Lin, J.Y., The Oxford Handbook of Africa and Economics, Volume 1, Context and Concepts, Oxford, Oxford University press, pp. 271-299.

Goalathe, N. (1997). Botswana's Boom and Recession Experience: A Discussion' in Salkin. J.S. et al., Aspects of the Botswana Economy: Selected Papers, Gaborone and Oxford: Lentswe La Lesedi Publishers, in association with James Currey Publishers. pp. 37-52.

Heywood, A., 2015. Political Ideologies: An Introduction, Hampshire: Palgrave MacMillan.

Himmelstrand, U., Kinyanjui, K., and Mburugu, E. eds. (1994). African Perspectives on Development: Controversies, Dilemmas \& Openings. London: James Currey Publishers.

Kasfir, N. (1998). African Ambiguities: No Party Democracy in Uganda, in Journal of Democracy, Vol. 9 Number 2, Johns Hopkins University Press. pp. 49-61.

Killick, T. (1989). A Reaction Too Far: Economic Theory and the Role of the State in Developing Countries, London: Overseas Development Institute.

Lewis, W. A. (1967). Report on Industrialisation and the Gold Coast. Accra:

Government Printing Department.

McCarthy, S. (1994). Africa: The Challenge of Transition. London, New York: I.B. Tauris \& Co. Publishers.

Meisenhelder, T. (1997). The Development State in Mauritius. Journal of Modern African Studies. Vol. 35, No. 2 pp. 279-297.

Mohamed Salih, M.A. (2001). African Democracies and African Politics. London, Sterling, Virginia: Pluto Press.

Mongredien, P. (2010). Things Fall Apart by Chinua Achebe, in The Guardian, 31 January, https://www.theguardian.com/books/2010/jan/31/ things-fall-apart-achebe-review Accessed 24 Feb. 2019. 
Ostergard, Jr. R. (2004). et al. Power, Politics and the African Condition: Collected Essays of Ali A. Marrui. Volume 111. Trenton, NJ: Africa World Press Inc.

Pillay, P. (2002). The Role of the State in Economic Development in Southern Africa, Dialogue on Globalisation. Berlin: Friedrich-Ebert-Stiftung Department for Development Policy - Dialogue of Globalisation.

Potter, D. (2000). Democratisation, Good Governance and Development in Allen. T. and Thomas, A., ed. Poverty and Development Into the $21^{\text {st }}$ Century. Milton Keynes: The Open University in association with Oxford University Press, pp. 365-382.

Rist, G. (1997). The History of Development: From Western Origins to Global Faith. London and New York: Zed Books.

Rodney, W. (1974). How Europe Underdeveloped Africa. London: Bogle L' Overture Publications Ltd.

Shutt, H. (1985). The Myth of Free Trade: Patterns of Protectionism Since 1945. Oxford: Basil Blackwell Ltd and London: The Economist Publications Ltd.

Siwawa-Ndai, P. Industrialisation in Botswana: Evolution, Performance and Prospects in Salkin. J.S. et al, ed. (1997). Aspects of the Botswana Economy: Selected Papers, Gaborone: Lentswe La Lesedi Publishers, and James Currey Publishers. pp. 335-367.

Stuenkel, O. (2017). Post-Western World: How Emerging Powers are Remaking Global Order, Cambridge and Malden MA: Polity Press.

The New Times. (2010). Book Review: Things Fall Apart by Chinua Achebe, 22 January. https://www.newtimes.co.rw/section/read/93649 Accessed 24 February.

World Bank. (2018). The World Bank in Botswana www.worldbank.org/ en/country/botswana Accessed 17 February 2019.

World Bank. (2019). Rwanda systematic Country Diagnostic: Report no. 138100-RW 25 June, International Development Association Country Department AFCE2 Africa Region.

Yoder, J. (2013). Elections as a Stress Test of Democratisation in Societies: A Comparison of Liberia, Sierra Leone, and the Democratic Republic of the Congo in C. Veney and D. Simpson, ed. African Democracy and 
Development, Challenges for Post-Conflict African Nations. Maryland: USA and Plymouth UK: Lexington Books. pp. 109-136. 2013. 